\title{
Quality Index Method developed for gutted and ungutted red tilapia (Oreochromis ssp)
}

\author{
Esquema del metodo índice de calidad desarrollado para tilapia \\ roja (Oreochromis ssp) eviscerada y sin eviscerar
}

\author{
Nelson Gutiérrez G, ${ }^{1 *}$ Ph.D, Claudia Amorocho $C_{1}{ }^{1}$ Ph.D, Angélica Sandoval A, ${ }^{2}$ Ph.D, \\ Yaneth Ruíz O, ${ }^{1}$ M.Sc.
}

\begin{abstract}
${ }^{1}$ Universidad Surcolombiana, Facultad de Ingeniería, Departamento Ingeniería Agrícola, Av. Pastrana Cra. 1 Neiva, Colombia. ${ }^{2}$ Universidad del Tolima, Facultad de Ingeniería Agronómica, Departamento producción y sanidad vegetal, Barrio Santa Helena, Ibagué Colombia. *Correspondencia: ngutierrezg@ usco.edu.co
\end{abstract}

Received: April 2014; Accepted: November 2014.

\begin{abstract}
Objective. To develop a Quality Index Method (QIM) for gutted and ungutted red tilapia from aquaculture ponds. Materials and methods. 40 specimens of gutted red tilapia and 40 ungutted ones were located in foam polyethylene boxes within layers of ice and storage at $4^{\circ} \mathrm{C}$. Three fish were randomly sampled on days $0,3,5,8,11,14$ and 17 for gutted tilapia, and on days $0,3,6,9,11$, 14 and 16 for ungutted tilapia. A sensorial panel of 8 experts was formed to evaluate the product. With three samples each day with average points of the sensorial attributes proposed in the method, the quality index for gutted and ungutted red tilapia was obtained based on the storage time on ice. Results. The Quality Index Method obtained for gutted and ungutted red tilapia showed maximum values of 21 and 29, respectively. It was adjusted in an increasing lineal model with high correlation between the Quality Index and the storage time on ice. Conclusions. The developed model is useful to determine deterioration levels and to define storage and consumption time. For gutted red tilapia the panel rejected the fish after 8 - 11 days of storage whereas the ungutted red tilapia was rejected after 6 - 9 days.
\end{abstract}

Key words: Cold storage, fish, freshness, sensory evaluation (Source: USDA).

\section{RESUMEN}

Objetivo. Desarrollar los esquemas del Método de Índice de Calidad (MIC) para la tilapia roja de piscifactoría eviscerada y sin eviscerar. Materiales y métodos. 40 especímenes de tilapia roja eviscerados y 40 sin eviscerar, fueron ubicados en cajas de polietileno expandido entre capas de hielo y almacenadas a $4^{\circ} \mathrm{C}$; se realizaron muestreos los días $0,3,5,8,11,14$ y 17 para tilapia eviscerada, mientras en la tilapia sin eviscerar los días $0,3,6,9,11,14$ y 16 ; se conformó un panel de 8 expertos para la evaluación sensorial de tres ejemplares en cada día de muestreo; con los puntajes promedio de los atributos sensoriales propuestos en el esquema, se obtuvo el índice de calidad para la tilapia roja eviscerada y sin eviscerar en función del tiempo de almacenamiento en hielo. Resultados. Los esquemas del Método índice de Calidad desarrollados para tilapia roja entera eviscerada y sin eviscerar, obtuvieron valores máximos de Índice de Calidad de 21 y 29 puntos respectivamente, ajustados a un 
modelo lineal creciente con alta correlación entre el Índice de Calidad y el tiempo de almacenamiento en hielo. Conclusiones. Los esquemas del MIC desarrollados son útiles para determinar el nivel de deterioro y definir los tiempos de almacenamiento y consumo. En la tilapia roja eviscerada los panelistas rechazaron el pescado para consumo entre los días 8 y 11 de almacenamiento, mientras que para la tilapia sin eviscerar el producto fue rechazado entre los días 6 y 9 de almacenamiento.

Palabras clave: Evaluación sensorial, frescura, pescado, refrigeración (Fuente: USDA).

\section{INTRODUCTION}

In Latin America the production on an industrial scale of species such as salmon, trout and tilapia has seen a notorious increase over the last decade, led by countries such as Brazil, Mexico, Ecuador and Chile. However, the development of aquiculture on a small scale begins to show notable possibilities in the market (1). Over the last two decades in Colombia an important progress has been made in the small to medium scale production of a hybrid tilapia known as red tilapia (Oreochromis $s s p$ ) in aquaculture ponds established in reservoirs to generate energy.

However, fish is a highly perishable product and a few hours after death a series of postmortem reactions occur, among them the autodegenerative reactions that are enzymatic and microbiological changes (2) that contribute to the detriment of the product (3) by the appearance of undesirable smells, colors and flavors which the final consumer rejects $(2,4)$. These changes are also manifested by the accumulation of organic compounds and microorganisms that can present a hygienic or toxicological risk for the consumer. Nevertheless, the final quality of the fish depends not just on the nature of the species, but also is implicitly related to handling and storage conditions $(5,7)$.

Different investigators and institutes in the fishing industry have developed methods to evaluate the freshness of fish, based on postmortem changes associated with sensorial, physicochemical and microbiological changes $(4,8)$. Included in these is appearance, smell, taste and texture, which have been establishes as the principle attributes of freshness $(9,10)$, and that is why the sensorial method is considered the most reliable to determine freshness of fish in relation to the physicochemical and microbiological methods $(10,11)$.

Sensorial evaluation is considered an important method to evaluate freshness (6) and quality (12), commonly used by control organisms in different countries to determine that fish complies with quality standards established by the fishing industry as part of quality control and by buyers to assure that the products meets their expectations (13).

\section{INTRODUCCIÓN}

En América Latina la producción a escala industrial de especies como el salmón, trucha y tilapia ha registrado un notorio crecimiento durante la última década, liderada por países como Brasil, México, Ecuador y Chile; no obstante, el desarrollo de la acuicultura en pequeña escala empieza a mostrar posibilidades notables en los mercados (1). En Colombia desde hace dos décadas se viene presentando un avance importante en la producción a pequeña y mediana escala de un hibrido de tilapias conocido como tilapia roja (Oreochromis ssp) en piscifactoría establecida en represas para generación de energía.

Sin embargo, el pescado es un producto altamente perecedero y unas pocas horas después de la muerte se presentan una serie de reacciones postmortem entre las que se destacan las reacciones autodegradativas de tipo enzimático y cambios microbiológicos (2), que contribuyen con el detrimento del producto (3); evidenciado en la aparición de olores, colores y sabores no deseados, los cuales causan rechazo por parte del consumidor final $(2,4)$, cambios que además son manifestados por la acumulación de compuestos orgánicos y microorganismos que pueden representar un riesgo higiénico o toxicológico para el consumidor. No obstante, la calidad final del pescado no sólo depende de la naturaleza de las especies, sino que además está implícitamente relacionado con el manejo y las condiciones de almacenamiento $(5,7)$.

Diferentes investigadores e institutos comprometidos con la industria pesquera, han desarrollado métodos para evaluar la frescura del pescado, basándose en medidas de cambios postmortem asociados con cambios sensoriales, fisicoquímicos y microbiológicos $(4,8)$. Dentro de estos, la apariencia, el olor, sabor y la textura, han sido establecidos como los principales atributos de frescura $(9,10)$; razón por la cual, el método sensorial es considerado como el más fiable para determinar la frescura del pescado en correlación con los métodos fisicoquímicos y microbiológicos $(10,11)$.

La evaluación sensorial considerada como un método importante para la evaluación de la frescura (6) y calidad (12); comúnmente utilizado por los organismos de control en diferentes países para determinar que el pescado cumple con los estándares de calidad establecidos por la industria pesquera, como parte del 
This characteristic has made, for instance, in the European legislation has established the use of such analysis, followed by a chemical or microbiological one, always when the sensorial evaluation determines it, in order to eliminate doubts about the product $(2,14)$. In Colombia, the activities of inspection, surveillance and control of fishing products, in particular fish, mollusks and fresh crustaceans, are regulated by means of Resolution 122 of 2012 (15) and are exclusively based on chemical and microbiological tests. Within those sensorial methods, different classification systems have been developed that are applicable to specific situations or to a limited number of fish species or products without having one particular defined method (11).

Over several years the Quality Index Method (QIM) has been used as a reference method in the European Union to determine the quality of sliced fish. The QIM is based on an objective evaluation of certain attributes of raw fish during storage on ice $(12,13,16)$. This evaluation should be done by trained personnel with clear and defined guidelines keeping in mind different attributes, such as the eyes, gills and scales, allowing accurate judgment about the product. The QIM has been catalogued as a precise and objective method, not destructive, quick, easy to apply and specific $(17,18,19)$. In the QIM each one of the analyzed attributes is qualified with a point system from 0 to 3, where zero represents the greatest indications of freshness and three determines the greatest indication of deterioration $(13,17,18)$. Points for each one of the analyzed attributes are added to give a total sensorial score for the day it is evaluated on; this way the Quality Index is achieved.

Due to the fact that higher scoring is given the longer the product is stored (18), the quality index is lineally increased $(13,18,20)$ and therefore is frequently used to predict the remaining storage time on ice $(12,18,21)$, which is useful for fish merchants to determine how much time it is acceptable to keep the product on the market (2). This method has been implemented to establish the degree of freshness in species such as: gilt-headed bream (Sparus aurata) (17,22, 23), red sea bream (Pagellus bogaraveo) (18), sardine (Sardinops sagax), (16), cod (Gadus morhua) (20), herring (Clupea harengus L.) (21), common octopus (Octopus vulgaris) (19), common cuttlefish (Sepia officinalis) (24), and red mullet (Mullus barbatus) (25), among others.

The objective of this investigation was to develop IQM model for gutted and ungutted red tilapia relating to the storage time on ice, and implicitly to study sensorial changes with results applicable control de calidad y por los compradores para asegurar que el producto cumple con sus expectativas (13).

Esta característica ha hecho que por ejemplo en la legislación europea, se haya establecido el uso de dicho análisis, seguido por uno químico y/o microbiológico, siempre y cuando la evaluación sensorial lo determine, con el fin de descartar sospechas sobre el producto $(2,14)$.En el contexto Colombiano, las actividades de inspección, vigilancia y control para los productos de la pesca, en particular pescados, moluscos y crustáceos frescos, reglamentadas mediante Resolución 122 de 2012 (15), están soportadas exclusivamente en pruebas químicas y microbiológicas. Dentro de los métodos sensoriales, se han desarrollado diferentes sistemas de clasificación, aplicables en situaciones específicas o en un número limitado de especies de pescado o productos, sin que se tenga definido uno en particular (11).

Desde hace unos años, se ha venido empleando el Método Índice de Calidad (MIC), como método de referencia en el marco de la Unión Europea para determinar la calidad del pescado en lonjas; el MIC se basa en la evaluación objetiva de ciertos atributos del pescado crudo durante su almacenamiento en hielo $(12,13,16)$. Esta evaluación debe ser realizada por personal entrenado con guías claras y definidas teniendo en cuenta diferentes atributos de manera simultánea, como el caso de ojos, branquias y piel, permitiendo realizar un dictamen acertado sobre el producto. El MIC ha sido catalogado como un método preciso y objetivo, no destructivo, rápido, fácil de aplicar y específico $(17,18,19)$. En el MIC cada uno de los atributos analizados, es calificado con una puntuación de 0 a 3 , donde cero es el puntaje que representa mayor índice de frescura y tres el puntaje que determina el mayor índice de deterioro $(13,17,18)$. Las puntuaciones para cada uno de los atributos analizados son sumadas para dar una puntuación sensorial total del día que se está evaluando; de esta manera se obtiene el denominado Índice de Calidad.

Debido a que las puntuaciones más altas se van dando en la medida en que avanza el almacenamiento (18), el índice de calidad se incrementa linealmente $(13,18,20)$, por lo que con frecuencia es utilizado para predecir el tiempo restante de almacenamiento en hielo $(12,18,21)$, lo que es de gran utilidad para los comerciantes de pescado para determinar por cuánto tiempo permanecerá aceptable su producto para la venta (2). Este método se ha implementado para establecer el grado de frescura de especies como: la dorada (Sparus aurata) $(17,22,23)$, besugo (Pagellus bogaraveo) (18), sardina (Sardinops sagax), (16), bacalao (Gadus morhua) (20), arenque entero (Clupea harengus L.) (21), pulpo común (Octopus vulgaris) (19), sepia común (Sepia officinalis) (24), y el salmonete (Mullus barbatus) (25), entre otros. 
both to the industrial sector as well as for regulatory entities of this food and agriculture product.

\section{MATERIALS AND METHODS}

Sampling and storage conditions. A total of 80 samples of commercial sized fish (380-420 g) were acquired from aquaculture ponds in the Betania reservoir, located in the south west of the department of Huila, $35 \mathrm{~km}$ from Neiva, where the greater amount of tilapia for the national and international market is produced. 40 fish with scales were gutted at the collection site, packed in expanded polystyrene boxes with ice, alternating layers of fish with layers of ice in a 1:1 proportion. Once packed, they were taken to the laboratory within an hour after acquiring them, and the polystyrene boxes were stored in refrigeration at a temperature that oscillated between 0 and $4^{\circ} \mathrm{C}$. Another 40 specimens were transported without gutting in the same conditions as the gutted fish. To analyze the gutted tilapia, sampling was done at $0,3,5,8,11,14$ and 17 days according to the methodology suggested by Simat et al (17), while the ungutted tilapia was sampled on days $0,3,6,9,11,14$ y 16 .

Sensorial model. A group of 8 expert panelists made up of academics, investigators and businessmen in the fishing sector were trained to do a sensorial evaluation by means of the Quality Index Method (QIM). An initial model for whole red tilapia was planned according to the one proposed by Martinsdóttir et al (13) for redfish due to its morphologic similarity to tilapia.

In gutted red tilapia, the aspects to evaluate through a developed model were: appearance (skin, blood in the gills, firmness), eyes (cornea, form, pupil), gills (color, smell, mucous) and meat (color and structure). Among others, the aspects for ungutted tilapia to evaluate were appearance (scales, blood in gills, firmness, belly), eyes (cornea, form, pupil), gills (color, smell, mucous) and meat (color and structure) and entrails (appearance, firmness and consistency).

The panelists evaluated each one of the established sensorial attributes on a scale of demerits from zero to three points, and judgments emitted for each evaluator were centralized in an numeral measurement. With the sum of the average scores of the sensorial attributes that were part of the QIM, a quality index was obtained for gutted and ungutted
El objetivo de esta investigación fue desarrollar los esquemas del MIC para tilapia roja eviscerada y sin eviscerar, en función de los días de almacenamiento en hielo, e implícitamente estudiar sus cambios sensoriales; con resultados aplicables tanto para el sector industrial como para las entidades reguladoras de este producto agroalimentario.

\section{MATERIALES Y METODOS}

Muestreo y condiciones de almacenamiento. Un total de 80 muestras de peces con un tamaño comercial $(380-420 \mathrm{~g})$ fueron adquiridas de una piscifactoría ubicada en el embalse de Betania, localizado al sur-occidente del departamento del Huila, a $35 \mathrm{Km}$ de la ciudad de Neiva, donde se concentra la mayor producción de tilapia para suplir el mercado nacional e internacional. 40 ejemplares con escamas fueron eviscerados en el sitio de recolección, embalados en cajas de poliestireno expandido con hielo, alternando capas de pescado con capas de hielo en una proporción 1:1. Una vez embalados, fueron llevados al laboratorio antes de transcurrir una hora después de su adquisición, las cajas de poliestireno fueron almacenadas en refrigeración a una temperatura que osciló entre 0 y $4^{\circ} \mathrm{C}$. Los otros 40 especímenes fueron transportados sin eviscerar en las mismas condiciones que el pescado eviscerado. Para los respectivos análisis en la tilapia eviscerada se hicieron muestreos los 0, 3, 5, 8, 11, 14 y 17 días, conforme a la metodología propuesta por Simat et al (17), mientras en la tilapia sin eviscerar los muestreos se hicieron a los días $0,3,6,9,11,14$ y 16 .

Esquema sensorial. Se conformó un grupo de 8 panelistas expertos integrado por académicos, investigadores y empresarios del sector piscícola, con experiencia en manipulación de tilapia roja, que fueron entrenadas para la evaluación sensorial mediante el Método de índice de Calidad (MIC). Se proyectó un esquema inicial para tilapia roja entera, similar al esquema propuesto por Martinsdóttir et al (13) para la gallineta nórdica por su similitud morfológica con la tilapia.

En la tilapia roja eviscerada, los aspectos a evaluar a través del esquema desarrollado fueron: apariencia (piel, sangre en los opérculos, firmeza), ojos (córnea, forma, pupila), branquias (color, olor, moco) y carne del filete (color y estructura). Entre tanto, en la tilapia sin eviscerar los aspectos a evaluar fueron: apariencia (piel, sangre en los opérculos, firmeza, vientre), ojos (córnea, forma, pupila), branquias (color, olor, moco) y carne del filete (color y estructura) y vísceras (apariencia, firmeza y consistencia).

Los panelistas valoraron cada uno de los atributos sensoriales establecidos, en una escala de deméritos de cero a tres puntos, los juicios emitidos por cada evaluador fueron centralizados con la media 
red tilapia (Oreochromis ssp) based on storage time on ice.

Statistical analysis. Data obtained from the value table as suggested by Sykes et al (26) were subjected to a lineal regressive analysis with a correlation between the quality index and the storage time on ice with a confidence level of $95 \%$.

\section{RESULTS}

QIM model for gutted red tilapia. Results of the sensorial evaluation done by the panel of experts for each one of the evaluated parameters provided the model of the quality index method for gutted red tilapia, and sensorial attributes were included that presented a notorious evolution during storage time. This way the developed model in the end had 4 quality parameters and 11 sensorial attributes, and the maximum total score was 21 points (Table 1 ).

In analysis done through the QIM model for gutted tilapia, the evolution of sensorial attributes such as "firmness" in the quality parameter, "appearance", the "form" in the "eye" parameter, "color" in the "gill" parameter and "structure" in the "meat" parameter were those that best reflected deterioration of the product's quality by showing a gradual evolution that increased during the 17 days of storage on ice (Figure 1).

With the total sum of the average score from the 11 sensorial attributes composed in the QIM model (Table 1), the quality index for gutted red tilapia (Oreochromis ssp) was obtained based on the storage time on ice (Figure 2).

The parameters that were included in the quality index model (Table 1) were useful to establish the detriment to the quality of gutted red tilapia during storage on ice and showed a high positive correlation $(R 2=0.98$; $\mathrm{p} \leq 0.01$ ) that shows its utility in determining the evolution of the loss of freshness in the fish. As can be seen in figure 2, the quality index increases as storage on ice advances, and reaches a maximum detriment value of 21 points on day 17.

QIM framework for ungutted red tilapia. The sensorial evaluation done by the panel of experts for each one of the parameters evaluated determined the quality index method model for ungutted red tilapia (Table 2 ). The aritmética; con la sumatoria de los puntajes promedio de los atributos sensoriales que hicieron parte del MIC, se obtuvo el índice de calidad para la tilapia roja (Oreochromis ssp) eviscerada y sin eviscerar en función del tiempo de almacenamiento en hielo.

Análisis estadístico. Los datos obtenidos de la tabla de valores tal y como lo sugieren Sykes et al (26), fueron sometidos a un análisis de regresión lineal, realizando una correlación entre el índice de calidad y el tiempo de almacenamiento en hielo con un nivel de confianza del $95 \%$.

\section{RESULTADOS}

Esquema del MIC para tilapia roja eviscerada. Los resultados de la evaluación sensorial realizada por el panel de expertos para cada uno de los parámetros evaluados, permitieron obtener el esquema del método índice de calidad para tilapia roja eviscerada, se incluyeron los atributos sensoriales que presentaron una evolución notoria durante el tiempo de almacenamiento. De esta manera el esquema desarrollado finalmente contó con 4 parámetros de
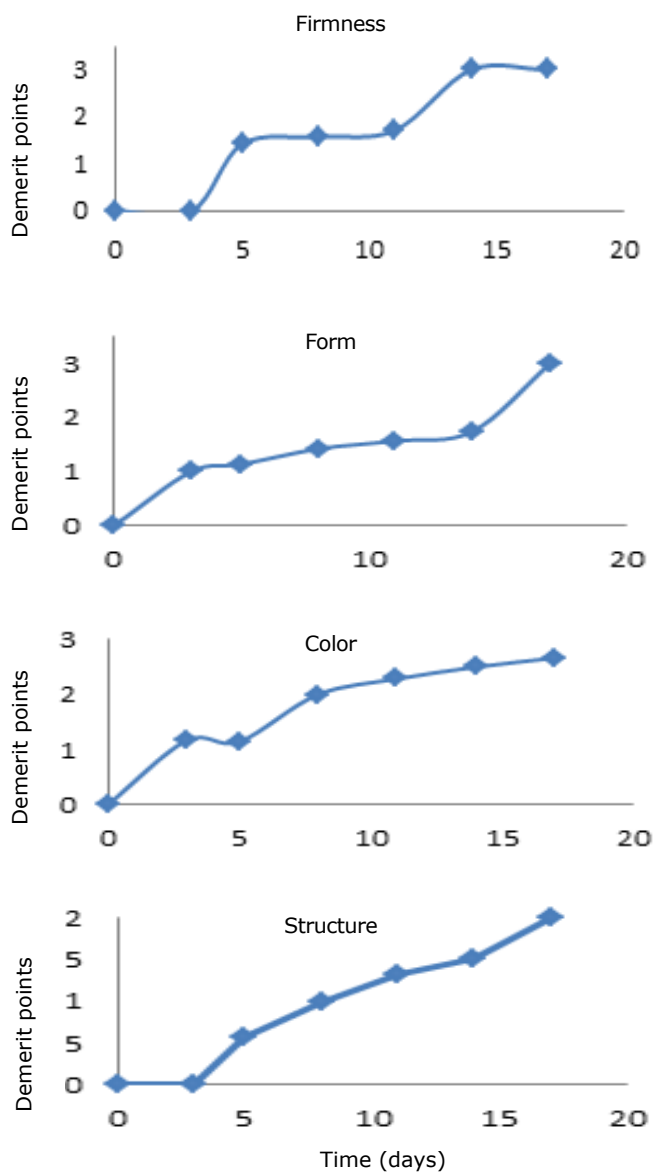

Figure 1. Evolution of sensorial attributes for gutted Red Tilapia stored on ice, based on storage time $(n=8)$. 
Table 1. QIM model for gutted red tilapia

\begin{tabular}{|c|c|c|c|}
\hline Quality F & Parameter & Scoring Description & Points \\
\hline \multirow[t]{9}{*}{ Appearance } & Scales & $\begin{array}{l}\text { Shiny, iridescent pigmentation, swollen } \\
\text { (healthy) }\end{array}$ & 0 \\
\hline & \multirow{4}{*}{ Blood in gills } & Somewhat matte, become discolored & 1 \\
\hline & & Absent & 0 \\
\hline & & Very little $(10-30 \%)$ & 1 \\
\hline & & A lot $(30-50 \%)$ & 2 \\
\hline & \multirow[t]{4}{*}{ Firmness } & In rigor & 0 \\
\hline & & $\begin{array}{l}\text { Firm, elastic (a fingerprint disappears } \\
\text { quickly) }\end{array}$ & 1 \\
\hline & & Soft (finger leaves a mark for 3 seconds) & 2 \\
\hline & & Very soft (leaves a mark for more time) & 3 \\
\hline \multirow[t]{10}{*}{ Eyes } & \multirow[t]{3}{*}{ Cornea } & Clear & 0 \\
\hline & & Opalescent & 1 \\
\hline & & Milky & 2 \\
\hline & \multirow[t]{4}{*}{ Form } & Convex & 0 \\
\hline & & Flat & 1 \\
\hline & & Slightly sunken & 2 \\
\hline & & Sunken, concave & 3 \\
\hline & \multirow[t]{3}{*}{ Pupil } & Black & 0 \\
\hline & & Opaque & 1 \\
\hline & & Grey & 2 \\
\hline \multirow[t]{11}{*}{ Gills } & \multirow[t]{4}{*}{ Color } & Blood red & 0 \\
\hline & & Similar to beef (less red) & 1 \\
\hline & & Faded, brown spots & 2 \\
\hline & & Brown, Faded & 3 \\
\hline & \multirow[t]{3}{*}{ Smell } & Slightly metallic & 0 \\
\hline & & Moderately metallic & 1 \\
\hline & & Metallic & 2 \\
\hline & \multirow[t]{4}{*}{ Mucous } & Clear & 0 \\
\hline & & Milky & 1 \\
\hline & & Coffee, clotted & 2 \\
\hline & & Faded, abundant clotting & 3 \\
\hline \multirow[t]{7}{*}{ Meat, filet } & \multirow[t]{3}{*}{ Color } & $\begin{array}{l}\text { Translucid, creamy color similar to flesh } \\
\text { with a slight pink color. }\end{array}$ & 0 \\
\hline & & Waxy, milky & 1 \\
\hline & & Opaque, yellow, brown spots & 2 \\
\hline & \multirow{4}{*}{ Structure } & Firm, defined myomers & 0 \\
\hline & & $\begin{array}{l}\text { Slightly friable, myomers moderately } \\
\text { defined myomers }\end{array}$ & 1 \\
\hline & & Friable, slightly defined myomers & 2 \\
\hline & & Quality index & $0-21$ \\
\hline
\end{tabular}



Figure 2. Changes in score of the quality index in gutted red tilapia based on storage time on ice $(n=8)$.
Table 2. E Quality Index model for ungutted red tilapia.

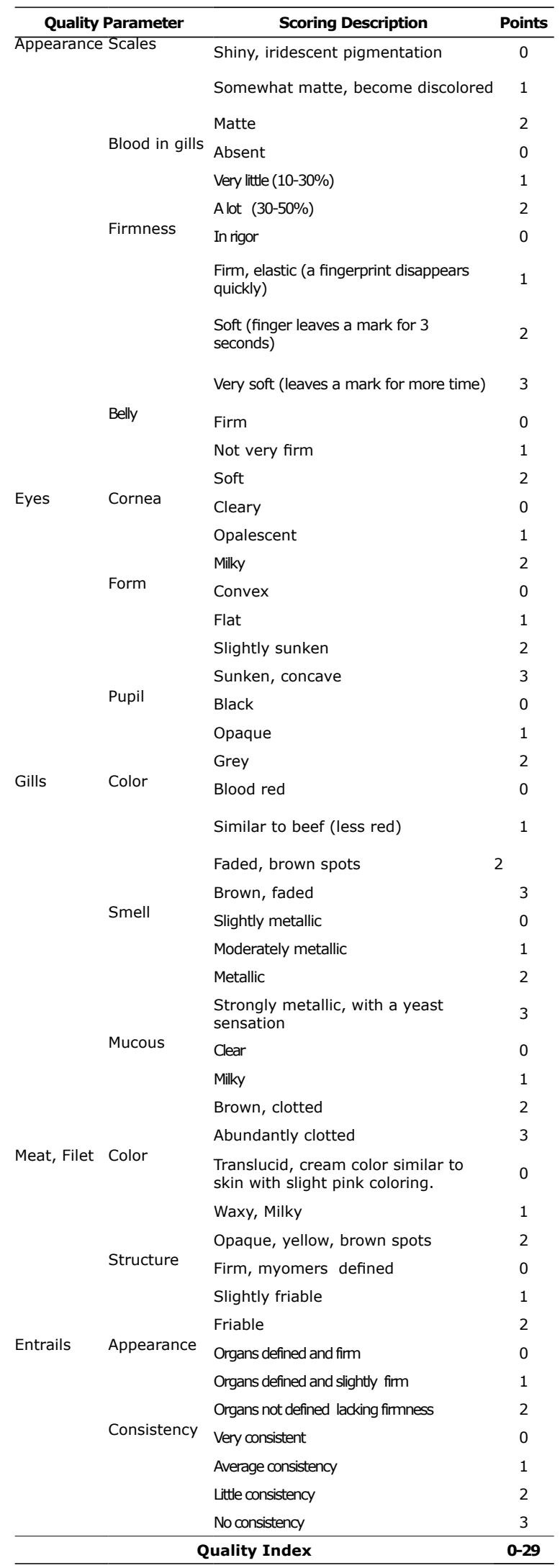



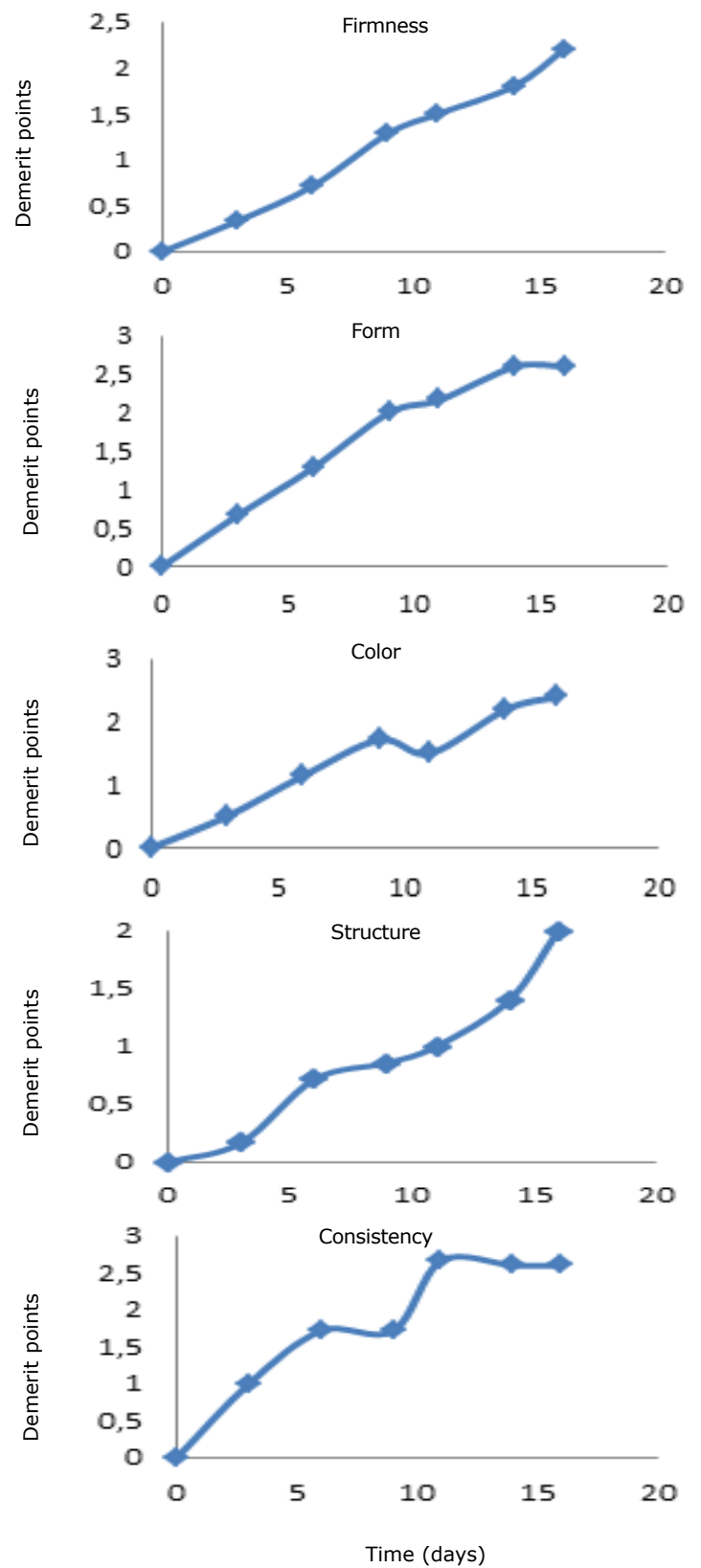

Figure 3. Evolution of the sensorial attributes in gutted Red Tilapia stored on ice, based on storage time $(n=8)$.

developed model had 5 quality parameters and 14 sensorial attributes, with a total maximum assigned score of 29 points of demerit.

In the case of ungutted tilapia, the evolution of the sensorial attributes "firmness" in the quality parameter "appearance", "form" in the "eye" parameter, "color" in the "gills" parameter, "structure" in the "meat" parameter and "consistency" in the quality parameter "entrails", were those that best reflected the

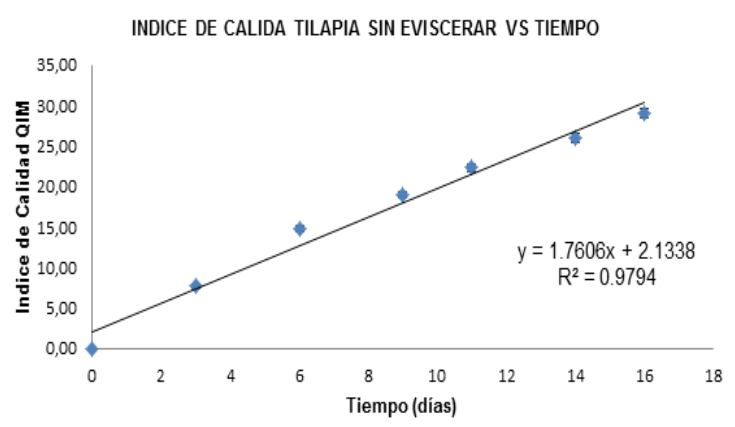

Figure 4. Changes in QI quality index score in ungutted tilapia based on storage times on ice $(n=8)$.

calidad y 11 atributos sensoriales, cuya puntuación máxima total asignada fue de 21 puntos (Tabla 1).

En los análisis realizados dentro del esquema MIC para tilapia eviscerada, la evolución de los atributos sensoriales como "firmeza" en el parámetro de calidad "apariencia", la "forma" en el parámetro "ojo", el "color" en el parámetro "branquias" y la "estructura" en el parámetro "carne, filete", fueron los que mejor reflejaron el detrimento de calidad del producto al presentar una evolución gradual creciente durante los 17 días de almacenamiento en hielo (Figura 1).

Con la sumatoria total de las puntuaciones promedio de los 11 atributos sensoriales que componen el esquema MIC (Tabla 1), se obtuvo el índice de calidad para la tilapia roja eviscerada (Oreochromis ssp) en función del tiempo de almacenamiento en hielo (Figura 2).

Los parámetros que se incluyeron en el esquema de índice de calidad (Tabla 1), resultaron ser útiles para establecer el detrimento de la calidad en tilapia roja eviscerada durante su almacenamiento en hielo ya que mostraron una alta correlación positiva $\left(R^{2}=0.98 ; p \leq 0.01\right)$, razón por la cual se demuestra su utilidad para determinar la evolución de la pérdida de frescura del pescado. Como puede verse en la figura 2 el índice de calidad aumenta a medida que avanza el almacenamiento en hielo, alcanzando un valor máximo de demérito de 21 puntos en el día 17.

\section{Esquema del MIC para tilapia roja sin eviscerar.} La evaluación sensorial efectuada por el panel de expertos para cada uno de los parámetros evaluados permitieron determinar el esquema del método índice de calidad para tilapia roja sin eviscerar (Tabla 2). El esquema desarrollado contó con 5 parámetros de calidad y 14 atributos sensoriales, cuya puntuación máxima total asignada fue de 29 puntos de demérito.

En el caso de la tilapia sin eviscerar, la evolución de los atributos sensoriales "firmeza" en el parámetro de calidad "apariencia", "forma" en el parámetro "ojo", "color" en el parámetro "branquias", "estructura" en 
changes in the product by presented a growing gradual evolution during 16 days of storage on ice (Figure 3).

With the total sum of average scores of the 14 sensorial attributes that make up the QIM model, the Quality Index for ungutted Red Tilapia (Oreochromis ssp) based on storage time on ice (Figure 4).

Just like with the gutted tilapia, the quality index obtained increased lineally regarding storage time on ice; finding a high positive correlation, adjusting the lineal model adequately ( $R 2=0.9794 ; p \leq 0.01)$, for which the parameters that were included in the quality index model (Table 2) were useful to establish the evolution of the loss of freshness in the fish. As can be seen in Figure 4, the quality index increased with storage time on ice, reaching a maximum demerit value of 29 points at day 16 .

\section{DISCUSSION}

In gutted tilapia, results obtained are similar to those found by Nielsen and Hyldig (21), who determined the shelf life of herring as being 8-14 days when the fish is caught in winter and 3-8 days when caught in autumn; similarly, Méndez (27) found the shelf life of fresh and unfrozen gilt-head bream to be 7 days, which matches the microbiological count obtained.

Additionally, following the recommendation of the group evaluator, the acceptation level of the product can be determined based on sensorial evaluation. Based on this, it is clear that QIM becomes a tool to aid any person with short training to decide on the deterioration level of red tilapia according to the analysis of attributes described in the model for storage conditions on ice as evaluated here.

The quality model index developed by evaluating the deterioration of gutted and ungutted red tilapia showed a gradual growing evolution, similar to the model developed for other species of fish $(18-20,28)$; additionally, in the two cases evaluated, the relation between the quality index and storage time were adjusted to a lineal model with high correlation values.

Other studies show reports in the case of sweet water species such as the hybrid tambacu or chacmoto (Colossoma macropomum $\mathrm{x}$ Piaractus mesopotamicus). In this case, QIM scores between 0 and 26 were reported with 5 quality parameters and 10 sensorial ones (29) el parámetro "carne/filete" y "consistencia" en el parámetro de calidad "visceras", fueron los que mejor reflejaron cambios en el producto al presentar una evolución gradual creciente, durante los 16 días de almacenamiento en hielo (Figura 3).

Con la sumatoria total de las puntuaciones promedio de los 14 atributos sensoriales que componen el esquema MIC, se obtuvo el Índice de Calidad para la Tilapia Roja sin eviscerar (Oreochromis ssp) en función del tiempo de almacenamiento en hielo (Figura 4).

Al igual que en la Tilapia eviscerada, el índice de calidad obtenido fue aumentando linealmente respecto al tiempo de almacenamiento en hielo; encontrando una alta correlación positiva, ajustándose de manera adecuada a un modelo lineal $\left(R^{2}=0.9794 ; p \leq 0.01\right)$, lo cual indica que los parámetros que se incluyeron en el esquema de índice de calidad (Tabla 2), resultaron ser útiles para establecer la evolución de la pérdida de frescura del pescado. Como puede verse en la figura 4 el índice de calidad aumenta a medida que avanza el almacenamiento en hielo, alcanzando un valor máximo de demérito de 29 puntos el día 16 .

\section{DISCUSIÓN}

En la tilapia eviscerada, los resultados obtenidos son similares a los encontrados por Nielsen y Hyldig (21), quienes determinaron una vida útil del arenque entre de 8-14 días en el pez capturado en invierno y de 3-8 días capturado en otoño; asimismo, Méndez (27), encontró una vida útil de la dorada fresca y descongelada de 7 días, tiempo concertado con el recuento microbiológico obtenido.

Además, atendiendo la recomendación del grupo evaluador, se puede determinar el nivel de aceptación del producto en función de la valoración sensorial. Con lo anterior queda claro que el MIC se constituye en una herramienta para que cualquier persona con un entrenamiento corto, pueda decidir sobre el nivel de deterioro de la tila roja en función del análisis de los atributos descritos en el esquema para las condiciones de almacenamiento en hielo aquí evaluadas.

Los esquemas de índice de calidad desarrollados para la evaluación del deterioro en la tilapia roja eviscerada y sin eviscerar, mostraron una evolución gradual creciente, similar a todos los esquemas desarrollados para otras especies de pescado $(18-20,28)$; además, en los dos casos evaluados la relación entre el índice de calidad y el tiempo de almacenamiento se ajustaron a un modelo lineal con altos valores de correlación.

Otros estudios reportan resultados para el caso de especies de agua dulce como el del híbrido de cachamoto (Colossoma macropomum $x$ Piaractus mesopotamicus), en este caso, se reportaron puntajes 
and the pacu (Piaractus mesopotamicus) that is found in rivers to the south of the continent, although in this case QIM scores were reported between 0 and 32, with 9 quality parameters and 15 sensorial attributes (30).

In the same way, the quality index values obtained based on storage time on ice resulted in the same order as those cited in other studies (18), reaching a maximum demerit value of 21 points on day 17 with gutted red tilapia and 29 points on day 16 with ungutted red tilapia.

In addition to determining the loss of freshness based on storage time, the QIM allows the indirect establishment of criteria to reject the product when needed for consumption or later transportation and processing. With the results of this study a maximum limit is proposed for consumption between 8 and 11 days of storage in gutted red tilapia and ungutted red tilapia, the product was rejected by the panelists between 6 and 9 days of storage.

For future investigations, it is proposed to compare the results of the evaluation of deterioration obtained by sensorial analysis, with results of the loss of freshness obtained with useful methods such as Torrymetro (18).

\section{Acknowledgements}

To the Universidad del Tolima for partial financing of this project (project: 290213). de MIC entre 0 y 26 con 5 parámetros de calidad y 10 atributos sensoriales (29) y el pacú (Piaractus mesopotamicus) que se encuentra en ríos del sur del continente, aunque en este caso se reportaron puntajes del MIC entre 0 y 32, con 9 parámetros de calidad y 15 atributos sensoriales (30).

De la misma forma, los valores de índice de calidad obtenidos en función del tiempo de almacenamiento en hielo resultaron del mismo orden que los citados en otros estudios (18) alcanzando un valor máximo de demérito de 21 puntos el día 17 en la tilapia roja eviscerada y 29 puntos el día 16 en la tilapia roja sin eviscerar.

Además de poder determinar la pérdida de frescura en función del tiempo de almacenamiento, el MIC permite de manera indirecta establecer criterios para el rechazo del producto cuando se requieren para su consumo o posterior transporte y procesamiento. Con los resultados de este estudio se propone como límite máximo para consumo entre 8 y 11 días de almacenamiento en la tilapia roja eviscerada y en la tilapia sin eviscerar, el producto fue rechazado por los panelistas entre los días 6 y 9 de almacenamiento.

Para futuras investigaciones, se propone comparar los resultados de la evaluación del deterioro obtenida con análisis sensorial, con los resultados de la pérdida de frescura obtenidos con métodos instrumentales como el Torrymetro (18).

\section{Agradecimientos}

A la Universidad del Tolima por la financiación parcial de este proyecto (proyecto: 290213)

\section{REFERENCES}

1. FAO. Organización de las Naciones Unidas para la Agricultura y la Alimentación [Internet]. El estado mundial de la pesca y acuicultura; 2010. [revisado 2013 dic 15]. URL Disponible en: http://www.fao.org/docrep/013/i1820s/ i1820s00.htm

2. Pons Sánchez-Cascado S. Estudio de alternativas para la evaluación de la frescura y la calidad del Boquerón (Engraulis encrasicholus) y sus derivados. [Tesis Doctoral]. Barcelona, España: Universidad de Barcelona, Departamento de Nutrición y Bromatología; 2005.

3. Sallam K. Antimicrobial and antioxidant effects of sodium acetate, sodium lactate, and sodium citrate in refrigerated sliced salmon. Food Cont 2007; 18(5):566-575.
4. Ocaño-Higuera VM, Maeda-Martínez AN, Marquez-Ríos E, Canizales-Rodríguez DF, Castillo-Yáñez FJ, Ruíz-Bustos $\mathrm{E}$, et al. Freshness assessment of ray fish stored in ice by biochemical, chemical and physical methods. Food Chem 2011; 125(1):49-54.

5. García-Soto B, Aubourg S, Calo-Mata P, BarrosVelázquez J. Extension of the shelf life of chilled hake (Merluccius merluccius) by a novel icing medium containing natural organic acids. Food Cont 2013; 34(2):356-363.

6. Calanche J, Samayoa S, Alonso V, Provincial $L$, Roncalés $P$, Beltrán J A. Assessing the effectiveness of a cold chain for fresh fish salmon (Salmo salar) and sardine (Sardina pilchardus) in a food processing plant. Food Cont 2013; 33(1):126-135. 
7. Rodríguez O, Losada V, Aubourg S, BarrosVelazquez J. Enhanced shelf-life of chilled European hake (Merluccius merluccius) stored in slurry ice as determined by sensory analysis and assessment of microbiological activity. Food Res Int 2004; 37(8):749-757.

8. Li T, Li J, Hu W. Changes in microbiological, physicochemical and muscle proteins of post mortem large yellow croaker (Pseudosciaena crocea). Food Cont 2013; 34(2):514-520.

9. Hernández M D, López M B, Álvarez A, Ferrandini E, García-García B, Garrido M D. Sensory, physical, chemical and microbiological changes in aquacultured meagre (Argyrosomus regius) fillets during ice storage. Food Chem 2009; 114(1):237-245.

10. Álvarez A, García-García B, Garrido M D, Hernández M D. The influence of starvation time prior to slaughter on the quality of commercialsized gilthead seabream (Sparus aurata) during ice storage. Aquacul 2008 284(1-4):106-114.

11. FAO. Food and Agriculture Organization of the United Nations [Internet]. Quality and quality changes in fresh fish. 1995. [revisado $2013 \mathrm{mar}$ 28]. URL Disponible en: http://www.fao.org/ DOCREP/V7180E/V7180E00.HTM

12. Pons-Sánchez-Cascado S, Vidal-Carou M C, Nunes M L, Veciana-Nogues M T. Sensory analysis to assess the freshness of Mediterranean anchovies (Engraulis encrasicholus) stored in ice. Food Cont 2006; 17(7):564-569.

13. Martinsdóttir $E$, Kolbrún $S$, Luten J, SchelvisSmith R, Hyldig G. La Evaluación sensorial de la frescura del pescado. Reikiavik Islandia: Eurofish; 2004.

14. Ministerio de Relaciones con las Cortes y de la Secretaria del Gobierno. España: Gobierno de España; 1993. (acceso 15 de marzo de 2013). Real Decreto 1437/1992: Normas sanitarias aplicables a la producción y comercialización de los productos pesqueros y de la acuicultura. Anexo Capítulo V: Controles sanitarios e inspección de las condiciones de producción. URL disponible en : http://www.boe.es/boe/ dias/1993/01/13/index.php.

15. INVIMA. Instituto Nacional de Vigilancia de Medicamentos y Alimentos; 2012. (acceso 18 julio de 2014). Resolución 122 - Enero 26/2012 Ministerio de Protección Social y Salud. URL disponible en: https://www. invima.gov.co/index.php?option=com_co ntent\&view $=$ article\&id =2798: resolucion- 122-enero-262012\&catid=303: resolucion2012\&Itemid $=2134$

16. Musgrove R, Carragher J, Mathews C, Slattery S. Value-adding Australian sardines: Factors affecting rates of deterioration in sardine (Sardinops sagax) quality during post-harvest handling. Food Cont 2007; 18(1):1372-1382.

17. Simat V, Bogdanovic T, Krzelj M, Soldo A, MarsicLucic J. Differences in chemical, physical and sensory properties during shelf life assessment of wild and farmed gilthead sea bream (Sparus aurata, L.). J Appl Ichthyol 2012; 28(1):95-101.

18. Sant'Ana LS, Soares S, Vaz-Pires P. Development of a quality index method (QIM) sensory scheme and study of shelf-life of ice-stored blackspot seabream (Pagellus bogaraveo). LWT-Food Sci Technol 2011; 44(10):2253-2259.

19. Barbosa A, Vaz-Pires P. Quality index method (QIM): development of a sensorial scheme for common octopus (Octopus vulgaris). Food Cont 2004; 15(3):161-168.

20. Bonilla A, Sveinsdottir K, Martinsdottir E. Development of Quality Index Method (QIM) scheme for fresh cod (Gadus morhua) fillets and application in shelf life study. Food Cont 2007; 18(4):352-358.

21. Nielsen D, Hyldig G. Influence of handling procedures and biological factors on the QIM evaluation of whole herring (Clupea harengus L.). Food Res Int 2004; 37(10):975-983.

22. Pérez J, Costell E. Estrategias de alimentación y cultivo de la Dorada Estado patológico y control de la calidad sensorial, Valencia (España), 2002.

23. Lougovois V, Kyranas E, Kyrana V. Comparison of selected methods of assessing freshness quality and remaining storage life of iced gilthead sea bream (Sparus aurata). Food Res Int 2003; 36(6):551-560.

24. Vaz-Pires $P$, Seixas P. Development of new quality index method (QIM) schemes for cuttlefish (Sepia officinalis) and broadtail shortfin squid (Illex coindetii). Food Cont 2006; 17(12):942-949.

25. Özyurt G, Kuley E, Özkütük S, Özogul F. Sensory, microbiological and chemical assessment of the freshness of red mullet (Mullus barbatus) and goldband goatfish (Upeneus moluccensis) during storage in ice. Food Chem 2009; 114(2):505-510. 
26. Sykes A, Oliveira A, Domingues P, Cardoso C, Andrade J, Nunes M. Assessment of European cuttlefish (Sepia officinalis, L.) nutritional value and freshness under ice storage using a developed Quality Index Method (QIM) and biochemical methods. LWT-Food Sci Technol 2009; 42(1):424-432.

27. Méndez Flórez E. Aplicación de la espectroscopía de impedancia en la evaluación de la calidad de dorada. [Tesis de Maestría]. Valencia, España: Universidad de Valencia, Departamento de Tecnología de Alimentos; 2011.

28. Billar dos Santos A, Mitsui M, Macedo E, LapaGuimaraes J. Development of Quality Index Method (QIM) scheme for Acoupa weakfish (Cynoscion acoupa). LWT-Food Sci Technol 2014; 57(1):267-275.
29. Borges A, Conte-Junior C, Franco R, Mársico E, Freitas M. Quality Index Method (QIM) for the hybrid tambacu (Colossoma macropomum $x$ Piaractus mesopotamicus) and the correlation among its quality parameters. LWT-Food Sci Technol 2014; 56(2):432-439

30. Borges A, Conte-Junior C, Franco R, Freitas M. Quality Index Method (QIM) developed for pacu (Piaractus mesopotamicus) and determination of its shelf life. Food Res Int 2013; 54(1):311-317 